\title{
Golden Handshakes: \\ Rewards for CEOs Who Leave
}

\author{
David Yermack \\ Department of Finance \\ Stern School of Business \\ New York University \\ 44 West $4^{\text {th }}$ St., Suite 9-160 \\ New York, NY 10012 \\ (212) 998-0357 \\ dyermack@stern.nyu.edu
}

August 2004

\begin{abstract}
This paper studies separation payments made when CEOs leave their firms. In my sample of Fortune 500 companies these packages are widespread and lucrative. Almost 80 percent of CEOs receive separation pay, and its mean present value exceeds $\$ 4.5$ million. Severance is positively associated with future pay that CEOs might expect until age 65 , and is higher when CEOs depart involuntarily. Shareholders react negatively when separation agreements are disclosed, but only in cases of voluntary CEO turnover. Some evidence suggests that severance pay acts as a bonding device between the board and CEO, while other evidence accords with theories of rent extraction.
\end{abstract}

I appreciate helpful comments from John Core and Kose John. 


\section{Golden Handshakes: \\ Rewards for CEOs Who Leave}

This paper studies "golden handshakes," the colloquial name for separation packages awarded to CEOs at retirement or termination. These severance agreements, somewhat similar to "golden parachutes" received by CEOs whose firms are acquired, can lead to controversy between shareholders and boards of directors. ${ }^{1}$ Because severance pay occurs when a CEO exits the firm, critics assert that it represents a giveaway that cannot influence future company performance. In addition, some severance packages go to CEOs who fail in their posts, and opponents charge that extra compensation for fired CEOs undermines incentives from the threat of dismissal, much the same as repricing might dilute performance incentives from executive stock options.

However, counter-arguments suggest that severance pay may be part of an efficient multi-period incentive contract. Life cycle theories of compensation, following Fama (1980), view severance pay as a means of "ex post settling up," under which a board of directors waits until the end of a CEO's career to assess his achievements and then compensates him with an

\footnotetext{
${ }^{1}$ For example, in June 2000 Procter \& Gamble Co. ousted Chairman and CEO Durk I. Jager, age 57, who in a brief tenure of 18 months had presided over a sizeable drop in the company's stock price. P\&G paid \$9.5 million to Jager in exchange for future consulting services and a promise not to compete, citing Jager's "loyal and distinguished service" as well as "arrangements provided by other companies to retiring chief executive officers." Jager also retained his previously awarded pension and stock options, according to P\&G's 2000 proxy statement. The next year, a shareholder resolution at the company's annual meeting assailed the package as "obscene" and proposed a ban on future severance pacts.
} 
appropriate exit package. The prospect of severance pay may also serve as a bonding device between the board and top managers, providing financial assurance that encourages younger CEOs to take risks that might be in shareholders' interests and not to take actions that entrench themselves in office (Almazan and Suarez, 2004). Severance pay may also benefit shareholders by helping the board protect corporate secrets and head off litigation or adverse publicity when a CEO is fired. ${ }^{2}$

Although golden parachutes have been investigated at length by researchers, no study has studied separation agreements for CEOs who retire or get dismissed by their boards. This paper examines a data set of 164 CEOs of Fortune 500 companies who leave their firms between 1996 and 2002. I gather data about the terms of each CEO's departure and classify different forms of separation pay into six categories. I perform regression analysis of the relation between severance pay and other elements of CEO compensation, and I analyze the stock market returns upon the disclosure of each CEO's package.

Perhaps the most striking result of the study is the ubiquity and size of severance pay for exiting CEOs. Seventy-nine percent of the executives in the sample collect some form of compensation upon leaving, with a mean present value of $\$ 4.52$ million including the zerovalued observations. The proportions are even higher for the sub-sample of CEOs who are dismissed; $84 \%$ of these executives receive severance packages of some type, with a mean present value of $\$ 7.11$ million. Twenty one of the 164 sample CEOs receive severance packages with present values in excess of $\$ 10$ million. These statistics significantly exceed the typical

\footnotetext{
${ }^{2}$ A number of prominent companies have in recent years become embroiled in public disputes and lawsuits with ex-CEOs after the company sought to limit or cancel their separation pay. Examples include Richard Grasso and the New York Stock Exchange, Jean-Marie Messier and Vivendi Universal, Bernard Ebbers and MCI, and Albert Dunlap and Sunbeam.
} 
payments to CEOs who receive golden parachutes. According to a recent study of 311 largefirm acquisitions by Hartzell, Ofek, and Yermack (2004), 69\% of all target company CEOs received golden parachutes after their firms were taken over, and these parachutes provided mean payments of $\$ 1.46$ million. Adding in special merger bonuses and parachute augmentations received by certain CEOs, the mean financial benefit to a CEO from golden parachutes, broadly defined, was about $\$ 3.0$ million in that study, some 50 percent less than the mean payment found herein for separation agreements for CEOs who leave without their firms being taken over.

Much of the separation pay received by CEOs is not transparent to shareholders. Twenty-one percent of the severance benefits obtained by CEOs in my sample take the form of enhancements to defined benefit pensions, which are reported only in indirect ways and require analytical sophistication for valuation. A further 27 percent of benefits are paid purportedly as compensation for service as Chairman of the Board after another executive has moved into the CEO position. Twenty-one percent represent payments due under pre-existing employment contracts, reaching as high as $\$ 36$ million for one terminated CEO. The remaining benefits take the form of lump-sum payments as well as agreements for the CEO to work as a consultant and/or not compete against the firm. These various sources of gains are offset in a handful of cases by value losses to CEOs from the truncation or cancellation of equity awards, mainly stock options that had not yet vested. Evidence presented below indicates that the opacity of separation agreements tends to increase when packages are larger than expected.

I use regression analysis to assess whether severance packages are statistically related to a CEO's past level of over- or under-compensation, in which case they might represent a rational 
form of ex post settling up. Similarly, I study whether associations exist with the present value of compensation that a CEO might have expected to receive had he worked until age 65 , in which case severance pay might serve as a consolation prize for CEOs who pursue attractive but risky projects that don't work out. I find no association between severance pay and past compensation, but a positive and significant connection with expected future compensation. CEOs appear to receive about 15 cents on the dollar in severance pay for the compensation they would have expected to earn up to age 65 , a result that changes little whether their departure is forced or voluntary.

Analysis of abnormal stock returns upon the disclosure of severance packages reveals a strong negative reaction, though it is confined to cases of voluntary CEO retirements (which represent the majority of the sample, about three-quarters). Company stock prices drop by an average of -1.33 percent when non-zero severance packages are disclosed; for the subsample of voluntary departures, the mean drop in stock prices is -1.92 percent (both statistics are highly significant). In contrast, the mean drop upon disclosure of non-zero severance packages for fired CEOs is -0.20 percent, insignificantly different from zero. Further regression analysis indicates a significantly negative association between the size of the package and the magnitude of the stock price reaction, with the result again confined to cases of voluntary, routine turnover.

Together these results suggest that shareholders view severance packages as an agency problem and symptom of poor governance when they're awarded to CEOs who leave under friendly circumstances, but that shareholders do not object to severance packages for CEOs who are forced out. This is consistent with a view that shareholders recognize the value of using golden handshakes to limit collateral damage to the firm from litigation, negative publicity, or 
disclosure of secrets by a disgruntled former CEO.

This paper's documentation of large payouts to CEOs when they leave their posts indicates that turnover, whether planned or forced, serves as a type of "compensation event" in which top managers often obtain extraordinary rewards on top of their regular annual pay. The findings complement other recent research into one-time rewards for CEOs who agree to sell their firms (Hartzell, Ofek and Yermack, 2004) and CEOs who make acquisitions (Grinstein and Hribar, 2004). Together these studies suggest that a full understanding of top management incentives requires looking beyond the effects of routine annual compensation. Until recently, annual pay has been the near-exclusive focus of the voluminous executive compensation literature. This is likely due in part to the way in which compensation is disclosed; recurring annual pay has been tabulated in a standard format since 1993 and coded into computer databases for research use, while compensation disclosure for unusual events such as CEO turnover often is relegated to fine print or footnotes that may not be published after the CEO has left the firm. Other episodes that may warrant scrutiny as lucrative CEO compensation events could include spinoffs, IPOs or equity carveouts, and even Chapter 11 bankruptcy filings.

The remainder of this paper is organized as follows. Section I reviews the theoretical literature on severance pay for top managers. Section II describes the data and sample selection process. Section III presents regression analysis of the value of severance packages. Section IV contains analysis of stock market reactions to the disclosure of these pacts. Section V concludes the paper.

\section{Theories of CEO severance pay}


This section of the paper describes four leading theories of why CEOs receive separation packages: (A) Ex post settling up, (B) Bonding, (C) Damage control, and (D) Rent extraction. Each sub-section provides detail about one theory as well as empirical predictions consistent with that theory.

\section{A. Ex post settling up}

Fama's (1980) model of how CEO wages are revised over time stresses that a board of directors continually obtains new information about the value of the CEO's human capital. A firm's operating results provide a noisy signal of the CEO's performance, and the precision of this signal becomes more clear over time. Changes to a CEO's permanent level of yearly compensation take account of this new information period by period, a dynamic that Fama labels ex post settling up. When the CEO is far from retirement, this approach implies that annual changes in compensation will be small, but as retirement approaches, annual changes will be large.

Though Fama's model does not deal explicitly with a CEO who reaches retirement, a clear implication of the ex post settling up process is that a manager who retires after a successful career will receive a large exit package, since his ability and effort will have exceeded the expected levels perceived by the board during his career. The board could deny the CEO his exit package, but this confiscation of value from the CEO would be demoralizing to other managers in the organization. Without the credible promise of a large exit package, those managers (including the successor CEO) would be discouraged from taking actions that were personally costly but beneficial to shareholders. 
In empirical studies of compensation, the ex post settling up theory of severance pay yields three predictions. First, severance pay should be inversely associated with the extent to which a CEO was over-compensated, based on the market value of his human capital, in the years leading up to retirement. Second, CEOs who are dismissed should receive little or no severance, since their ability probably proved to be lower than expected. Third, the disclosure of severance pay should be expected by shareholders and should not represent new information that leads to changes in firm value, unless it is awarded in patterns that are inconsistent with the first two empirical predictions immediately above.

\section{B. Bonding}

Almazan and Suarez's (2004) formal model of severance pay illustrates its usefulness for inducing a CEO to take value-increasing actions that he would otherwise avoid. In their model, shareholders decide on a compensation contract for the CEO and also on whether to establish a "strong" or "weak" board of directors. The optimal level of severance pay in the CEO's contract is sensitive both to the quality of the board and also to the characteristics of the investment projects available to the firm. The choice of a strong or weak board also depends upon the characteristics of investment projects as well as information asymmetries between the CEO and board.

In one case of Almazan and Suarez's model, a strong board can replace the CEO with a better-qualified rival should one become available. If the CEO perceives the possibility of future replacement as high, he will resist taking actions now, such as risky positive NPV investments,

that would be personally costly in the short-term but would be expected to yield benefits to 
himself and to shareholders in the long-term. Severance pay solves this incentive problem by discouraging the board from changing CEOs in the future if the cost of the severance package exceeds the expected benefits from better management. Severance pay therefore serves as a bond, posted by the board, to assure the CEO of a certain level of future utility. The existence of this bonding device elicits better short-term management decisions.

In an alternative case of the model, in the presence of a weak board the CEO is able to exert control over corporate governance in a way that entrenches him against any threat of removal. With this job security, he is unlikely to take actions today that benefit shareholders in the future if those actions have short-term personal cost. The inclusion of severance pay in the compensation contract offers the manager an incentive to exit the firm in the future if he is not prepared to take value-increasing actions that are expected to have large future payoffs, since the value of the severance package would exceed his expected performance-based compensation if he stayed.

Almazan and Suarez summarize their analysis of severance pay by writing, "In strong boards, it protects the CEO from the shareholders' tendency to replace him too frequently. In weak boards, it protects shareholders from the CEO's tendency to resist excessively his own replacement." They make one empirical prediction: that weak boards should negotiate CEO compensation contracts with larger pay-performance sensitivity and also larger severance pay than contracts written by strong boards.

Almazan and Suarez's bonding model should imply three additional empirical predictions. First, severance pay should not be confined to successful CEOs, but should also be awarded to CEOs who are dismissed for poor performance. Second, one should find a positive 
association between the value of a separation package and the present value of compensation that a CEO would have earned up to regular retirement age, since the bond posted by the board involves guaranteeing the CEO a lifetime income floor. Third, stock returns may be positive when severance agreements are publicized, especially in cases of forced turnover, since they may indicate that the board had coaxed an ineffective CEO into retirement.

However, it's not clear from empirical data that Almazan and Suarez's model has great relevance for describing severance pay as actually awarded by firms, for two reasons. First, as shown by the data below, only a minority of severance pay is delivered according to prenegotiated contracts, which is the framework used in their model. This type of advance commitment by the board would seem necessary for severance pay to function as a credible bond. Second, the objective function in Almazan and Suarez's model involves minimizing the total executive compensation expense for the firm. This may appear to be a minor issue with most large firms, since the cost of severance packages is generally only a tiny fraction of firm value, and the potential for value destruction by an inept CEO greatly exceeds the severance package that would likely be necessary to induce him to retire.

\section{Damage control}

In addition to the reasons illuminated by formal economic models, more prosaic considerations may also cause firms to make large exit payments to their CEOs.

Most CEOs who retire, whether on a forced or voluntary basis, leave their posts with valuable corporate secrets as well as firm-specific human capital that may be useful to the

company in some form. Severance pay often takes the form of non-competition agreements and 
consulting contracts in order to keep corporate secrets out of the hands of rival firms, and/or to allow the CEO to continue contributing his skills to the company on a reduced basis. Severance pay may also prevent a disgruntled CEO from suing the board of directors, sounding off in the news media, sabotaging the transition between himself and his replacement, or even notifying regulatory authorities about irregular business practices.

If severance pay helps limit the costs to the firm from CEO turnover in these and other ways, three empirical predictions would follow. First, separation packages should go to dismissed CEOs at least as often as those who retire as planned. Second, no particular relation should emerge between severance pay and either past over-compensation or future expected compensation. Third, the disclosure of severance packages should ordinarily be a positive event for shareholders, since they would indicate that the firm had taken actions to limit costs that otherwise might be high.

\section{Rent extraction}

In line with the frequent portrayal of separation agreements in the news media, a further theory of severance pay would be that it represents rent extraction by powerful managers who are able to obtain extra compensation beyond the value of their human capital. A thorough statement of this theory appears in Bebchuk and Fried (2004).

The rent extraction theory of severance pay would imply several empirical predictions.

First, CEOs who were over-compensated prior to retirement should also receive higher severance pay, since their ability to obtain excess compensation should be high at both the

middle and the end of their careers. Second, more valuable packages should be awarded to 
CEOs who leave voluntarily and also to CEOs in firms with weak boards of directors, since these executives would appear to have greater control over their firms' governance. Third, severance pay should result in negative stock returns upon announcement, since its disclosure would indicate that resources had been transferred from shareholders to the retiring CEO and, more generally, that the firm's governance was too ineffective to prevent such a transfer. Fourth, stock returns should be more negative to the extent that separation pay is delivered in an opaque form, such as pension enhancements, instead of transparently through such devices as lump-sum bonuses. A non-transparent separation package should indicate that the board and CEO wanted to conceal the full details of the arrangement, which would seem likeliest if the pay occurred due to rent extraction instead of one of the other theories described above.

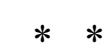

Table I summarizes the empirical predictions associated with each of the four theories of severance pay discussed above.

\section{Sample selection and description}

\section{A. Sample Selection}

Analysis of CEO turnover events in this paper is based on a panel of 237 companies that were members of the Fortune 500 in 2002. Beginning with the entire Fortune 500, I drop all non-public firms and all firms not covered by ExecuComp for the entire ten-year period 19932002. Because certain analysis below of CEOs' prior compensation requires three years of lagged data, the sample for turnover analysis spans the seven-year period 1996-2002 with 1993- 
95 data reserved for use as lagged values in the measurement of past compensation. The candidate sample therefore includes seven observations for each of 237 firms, or 1,659 companyyears.

Table II describes the construction of the sample of turnover events used in the paper's analysis. Within the entire sample universe, companies change their CEOs 211 times, including CEOs from the final sample year 2002 who are replaced in 2003. The CEO turnover frequency of $12.7 \%$ is slightly higher than found by past turnover studies, but in line with a trend toward greater turnover rates that has occurred over the past 40 years (see studies cited by Denis and Denis, 1995).

Because this study focuses on compensation received by exiting CEOs in separation agreements, I narrow my sample by eliminating several types of turnover events in which separation agreements were either irrelevant, extraordinary, or influenced by external events that overshadowed the change in management. These observations include four turnovers due to death or ill health; four cases of CEOs who left for better positions (three became CEOs of larger companies, and one became the U.S. Secretary of the Treasury); six acting CEOs who left after a short tenure; three CEOs who left due to scandals involving legal action (one each for narcotics smuggling, sexual harassment, and fraud); thirteen corporate restructurings in which the CEO's exit was negotiated as an antecedent to the transactions (nine mergers and four spinoffs); and one case in which a turnover occurred and the CEO's compensation information was omitted from the next year's proxy statement in violation of the SEC's disclosure rules. I also omit 16 observations in which the CEO title was transferred to another person but the departing CEO remained as an officer of the firm, usually as Chairman of the Board, and continued to draw 
compensation at least as large as his successor. These cases, the majority of which involve company founders such as Bill Gates and Charles Schwab, do not appear to represent genuine turnover events, and a number of these executives later resumed the CEO position after becoming dissatisfied with their successors. In all, the removal of 47 events from the sample leaves 164 cases for analysis of the terms of CEOs' separations.

I follow the standard approach in the CEO turnover literature by partitioning the observations into voluntary (or "planned") and involuntary (or "forced") subsamples. For the large majority of observations, whether the turnover is voluntary can be ascertained from news media reports and/or descriptions of the event in company proxy statements. In borderline cases, I also consider such factors as the exiting CEO's age and performance record, his continuing role with the firm if any, the amount of time elapsed between announcement of the CEO's exit and his actual departure, and whether the successor CEO came from outside the firm. I classify 43 events, or $26.2 \%$ of the turnovers analyzed, as forced, with the remainder as voluntary. These percentages are close to those in Huson, Parrino and Starks (2001) who classify $23.4 \%$ of turnover events as forced in a 1989-94 sample.

\section{B. Sample Description}

Table III presents descriptive statistics about the sample of 164 turnover events, with the full sample properties shown in the left column and data for the planned and forced subsamples shown in the other two columns. The typical exiting CEO is 61 years old with nine years of service, and unsurprisingly, CEOs who leave voluntarily have significantly higher mean values of these statistics compared to CEOs who are dismissed. CEOs own a mean of $\$ 92.2$ million 
(median of \$34.7 million) of stock plus options their firms, with option values calculated according to Black-Scholes methodology based upon option inventories disclosed in proxy statements. The representative $\mathrm{CEO}$ in the sample also has a defined benefit pension plan with a mean present value of $\$ 6.4$ million (median of $\$ 4.5$ million). Though they are almost always overlooked in CEO compensation research, pension values are important in this paper because, as shown below, a significant amount of value is delivered to exiting CEOs in the form of pension enhancements. I estimate the present value of firms' pension obligations from annuity calculations using male and female mortality tables disseminated by the U.S. Social Security Administration. Other inputs to the pension value calculations include the firm's annual payout to the retired executive, the age at which payouts begin, the form of the annuity (such as life or joint and survivor), and the firm's cost of debt. The first three items can be obtained or inferred from information in the annual proxy statement, and firms' costs of debt are estimated using Moody's bond rating histories for each company. For joint and survivor annuities, I assume that the $\mathrm{CEO}$ is married with a spouse of the same age. Equity ownership and pension values are significantly lower for CEOs whose departures are forced as opposed to voluntary, because the accumulation of both equity and pension value is closely linked to tenure in office.

Annual compensation, representing the sum of salary, bonus, stock option award values, and restricted stock award values, has a mean of $\$ 8.1$ million (median of $\$ 4.4$ million) for CEOs in their last full year prior to the turnover year (CEOs who leave after less than two years in office are not counted in this calculation). Compensation is significantly higher for CEOs who are forced out, compared to those who retire voluntarily, a somewhat surprising result. I estimate whether CEOs have been over- or under-compensated in the past relative to their peers, 
as a prelude to evaluating whether their separation packages represent a form of ex post settling up. I estimate the extent of each CEO's past excess compensation using the ExecuComp variable for three-year compensation, for the period ending in the last full year prior to the turnover year (the turnover year must be omitted from the calculation, because it often includes the value of the separation package). I regress the log of each CEO's prior three-year compensation against the log of sales, the firm's three-year net-of-market stock return compounded continuously, and dummy variables for two-digit SIC industries and individual years. The regression sample includes the latest observation for all ExecuComp CEOs for whom the three-year compensation and stock return variables are not missing; the sample analyzed contains 2,072 observations, the estimated regression has an r-squared of 0.456 , and estimated coefficients are 0.41 for the log of sales and 0.14 for the three-year stock return, both highly significant. For the 164 exiting CEOs in my sample, 121 have enough information to be placed in the regression sample. I save the residuals from the excess compensation regression, exponentiate them, and estimate prior excess compensation as the difference between actual three-year compensation and the residual. Since regressions are based on logged values of compensation but I calculate excess compensation after removing the log, mean values of excess compensation are positive for all CEOs in the sample, while median values are very close to zero. No significant difference exists between the past excess compensation of CEOs who are forced out compared to those who retire voluntarily.

I track the subsequent positions, if any, that exiting CEOs hold with their firms. An enormous disparity exists between the data for CEOs who leave voluntarily and those that are dismissed. Of the 121 cases of voluntary turnover, 84 former CEOs (more than two-thirds) 
remain as Chairman of the Board for at least a period of transition, while another 15 remain on the board of directors. Only 15 of 121 resign all their positions with the firm immediately upon relinquishing the CEO title. These data would skew even more heavily toward continued involvement of voluntarily retired CEOs if the analysis included the 16 cases discussed above of “non-retiring” CEOs who continue indefinitely as highly compensated officers, usually as Chairmen of the Board. In the forced subsample of 43 CEO turnovers, about two-thirds, or 29 CEOs, resign all positions immediately, while 11 others become chairmen of the board for a nominal period.

Table III also tabulates various information about the size and governance of the sample firms included in the analysis. In general, no unusual patterns or significant differences exist for these variables in the overall sample or in the forced vs. voluntary turnover subsamples, except that boards of directors are slightly smaller for firms with forced turnover events, a result in line with Yermack's (1996) finding of a greater performance-turnover sensitivity in companies with small boards.

\section{Elements of CEO separation agreements}

To analyze the value of CEO separation agreements, I disaggregate the data into six categories as described below. Table IV presents descriptive statistics about each of these categories as well as the total values of packages received by the 164 departing CEOs in the

sample. The top panel of Table IV includes data for the entire sample; the middle and bottom panels include data for voluntary and forced turnover, respectively.

I divide value transfers to CEOs from their separation agreements into the following 
categories:

- Lump-sum payments. These include unconditional awards of cash, forgiveness of outstanding loans from the company, and in some cases, awards of stock or stock options. Data in the top row of Table IV indicate that 24 percent of all exiting CEOs receive transfers of this type. The mean value per CEO is $\$ 1.05$ million including the zero observations, meaning that when lump-sum payments are actually made, their average value exceeds $\$ 4$ million. The maximum value in the sample is nearly $\$ 22$ million. Rather than label these payments as "severance pay," firms generally characterize them as consideration for such things as "effecting a smooth transition to his successor," "leadership in the management transition process," or the CEO's "personal sacrifice" of electing early retirement.

- $\quad$ Consulting and non-compete agreements. Many companies enter into contracts that will be paid out over a number of years, in consideration for the exiting CEO's agreement not to compete against the company, and/or to serve as a consultant. I take the present value of these payments, discounted at the firm's cost of debt. About 25 percent of the sample CEOs enter into agreements of these types, with a mean present value of about half a million dollars.

- $\quad$ Pension augmentations. Many CEOs obtain enhancements to the lifetime defined benefit pensions that they would ordinarily receive. The annual pension payment for an executive often depends upon length of service, and many companies will add extra service time or permit exiting CEOs to begin drawing their full pensions immediately instead of waiting until the normal start date (usually age 65). Data in Table IV indicate that about one-fifth of departing CEOs receive enhanced pensions, with the practice being much more common with CEOs who leave involuntarily (40 percent frequency) compared to voluntarily (13 percent). The mean value increase per CEO is just under $\$ 1$ million, but pension enhancements can be worth as much as \$15 million to the CEOs in the sample. These adjustments can be extremely opaque to shareholders or analysts reading company proxy statements. ${ }^{3}$

- $\quad$ Forfeiture of stock or options. Most CEOs hold unvested stock options and restricted stock when they leave. Although no clear disclosure is made in many cases, the overwhelming practice appears to be that companies permit all shares and options to vest upon a CEO's departure. In a handful of cases, amounting to nine events in the entire

\footnotetext{
${ }^{3}$ As an example, J.P. Morgan Chase CEO Walter Shipley retired in 1999 at age 63. According to the company's 1999 proxy statement, he was due to receive $\$ 897,577$ beginning at age 65 in the form of a joint and $50 \%$ survivor annuity. The next year, the 2000 proxy statement reported that Shipley had begun drawing a $\$ 1,600,000$ annual pension at age 64 as a joint and 100\% survivor annuity. The combination of the three adjustments -- increasing the annual amount, changing the form of the annuity to $100 \%$ survivor, and permitting the CEO to draw the pension one year early -- increased its present value by more than $\$ 7.5$ million, based upon actuarial calculations using the firm's cost of debt. No explanation was provided for these changes, and no disclosure was made of the overall value consequences for shareholders.
} 
sample and all but one involving forced turnover, companies do not permit unvested shares to vest or truncate the time in which certain options may be exercised. Data in Table IV reflect the value losses as a result of these changes, which can exceed $\$ 10$ million. An open question, not directly addressed by most firms, is whether CEOs are permitted to retain their unexercised options for their full remaining terms of up to 15 years, or whether they must exercise within the standard period for executives who leave the firm, which is often between 30 and 90 days. A large number of CEOs appear to retain their options according to their original terms because they continue as members of the board of directors. ${ }^{4}$ Unless a company's filings make clear disclosures about time limits in which options must be exercised, I assume that options lives are not shortened.

I refer to the sum of these four categories of severance pay as the "incremental package"

received by each CEO, since value is not delivered pursuant to any pre-existing agreement, and since the CEO must perform only nominal future service for the firm. Most of the regression analysis below is based on the value of these incremental packages. Data in Table IV show that about half of all CEOs, and two-thirds of CEOs who are dismissed, receive incremental packages with positive value. The mean value per CEO exceeds $\$ 1.8$ million in cases of friendly turnover, and \$3.9 million for forced turnovers.

I tabulate two additional categories of separation pay:

- $\quad$ Settlement of employment contracts. Especially in forced terminations, CEOs often collect from their firms the balance due under pre-existing employment contracts. Table IV tabulates data about these payments, which can involves as much as five years worth of salary, bonuses, and other guaranteed remuneration. The sample includes three cases of dismissed CEOs who received more than \$28 million, \$31 million, and \$36 million, respectively, in settlement of their contracts. These events are often among the most objectionable to shareholders, but they do not represent an incremental cost to the firm, since the company was already liable for the payments under the managers' contracts.

- Compensation for service as Chairman. Very often exiting CEOs remain as Chairman of the Board, even in a few cases of forced turnover, and it is common for their compensation to remain at the CEO level for at least one to two years. It is not clear whether this remuneration should be viewed as disguised severance pay or whether the

\footnotetext{
${ }^{4}$ In addition, numerous companies' annual option disclosures in proxy statements indicate that former CEOs continue to own their full complement of options after leaving the company, even in situations where exiting employees ordinarily would have been required to exercise within 30 to 90 days.
} 
former CEO is genuinely earning additional pay. I take the present value of all remuneration received by exiting CEOs who remain on the payroll while serving as Chairman, with the exception of regular fees received by all non-employee members of the board, and this data is shown in Table IV. ${ }^{5}$ Chairman compensation is non-zero for nearly half of the sample CEOs and can be quite large, with one CEO collecting more than $\$ 42$ million for a 20-month stint as Chairman (largely due to two very large stock option awards). As noted above, sixteen additional CEOs who are not counted as part of the sample also draw large compensation as Chairman after giving up the CEO title to someone else, and then remaining in the Chairman's position indefinitely at a high pay level.

Adding these two additional categories of separation pay to the analysis results in the "total pay" for each CEO shown in the last line of each panel of Table IV. Overall, the mean package per CEO is about $\$ 4.5$ million, with nearly 80 percent of the sample receiving at least one of the six categories of compensation. A comparison of voluntary vs. forced CEO replacements indicates that separation pay is significantly different across the two subsamples in every category. Dismissed CEOs generally receive larger packages, with a mean value of $\$ 7.1$ million compared to $\$ 3.6$ million. However, they are far less likely to receive compensation for service as Chairman and more likely to have to forfeit valuable equity awards that have not yet vested.

In addition to these categories of remuneration, many exiting CEOs obtain a variety of fringe benefits, often continuing to receive perquisites that they enjoyed while in office. Companies often pay for country club memberships, personal use of corporate aircraft, the cost of maintaining an office, premium health coverage, and so forth. I do not include these items in

\footnotetext{
${ }^{5}$ A definitional issue arises if an executive gives up the CEO title part-way through the year but remains as Chairman until year-end or beyond, drawing full CEO-level compensation for the entire twelve months. In these cases I pro-rate the executive's salary according to the date of departure. Stock option awards are classified as Chairman-only compensation if the award date occurs after the executive leaves as CEO. Bonuses are classified as Chairman-only compensation if the executive serves only a minority of the year as $\mathrm{CEO}$, since bonuses typically are awarded at yearend.
} 
my calculations due to the impossibility of valuing them in most cases. I also do not include CEO wealth increases that occur when the firm's stock price reacts to announcement of the change in CEOs. In some cases of forced turnover, company stock prices rise substantially, giving the exiting CEO the consolation of a large appreciation in his equity holdings. ${ }^{6}$

\section{Summary}

Basic summary statistics about separation packages indicate that a large majority of CEOs receive them, and they are often very valuable. Considerable variation exists across firms in how severance pay is delivered, whether through lump-sum payments, improvements to pensions, or compensation for service as a consultant or board chairman. Severance pay is awarded widely for both forced and voluntary turnover. This near-uniform use of severance pay would seem most consistent with either the bonding or damage control theories, according to the empirical predictions outlined in Section I above and tabulated in Table I.

\section{Regression analysis of the separation packages}

I undertake regression analysis of the value of CEO separation packages to evaluate the explanatory power of theories of severance pay detailed above. Because of the large number of zero-valued separation packages, I estimate Tobit regressions, the results of which appear in

\footnotetext{
${ }^{6}$ For example, when Bank One Corp. announced CEO John B. McCoy’s departure on December 22, 1999, the company's stock rose by $\$ 3.375$, more than 10 percent. McCoy's personally owned shares and options increased in value by more than $\$ 3$ million due to the announcement effect.

McCoy, age 57, also received a $\$ 10.3$ million lump-sum severance payment; a pension increase with a present value exceeding \$1 million; immediate vesting of certain options, restricted shares, and deferred compensation; office space and secretarial support for life; moving expenses; and a promise of reimbursement for any loss on the sale of his residence. The company wrote in its 2002 proxy statement that the board's compensation committee was "satisfied as to the appropriateness of the terms of [McCoy's] agreement," but Bank One's stock fell by a market-adjusted 1.61\% upon disclosure of its terms.
} 
Table V. The left column of the Table presents Tobit estimates for a model with the dependent variable equal to each CEO's incremental separation package, as defined above in Table IV. The right column of Table $\mathrm{V}$ presents the same regression model with the dependent variable equal to the entire separation package value. The key explanatory variables in Table V's regressions are compensation related. I also include the log of total assets in all models to control for the effects of firm size, as well as year and industry dummy variables.

\section{A. Expected future compensation}

Expected future compensation for each CEO is the present value of expected annual compensation for each year until the CEO reaches age 65. For CEOs age 65 and over, it equals zero. In the regression estimates shown, I use the sample median annual compensation of about $\$ 4.4$ million as the expected level of annual pay for each CEO; this total includes salary, bonus, stock option awards, and restricted stock awards. The discount rate for calculating the present values of expect future pay is each firm's cost of debt, inferred from Moody's bond ratings.

Estimates in Table V indicate a clear positive association between expected future compensation and the value of CEOs' separation packages. The coefficient estimates of 0.14 and 0.15 imply that CEOs receive approximately 15 cents for each dollar of compensation (present value) that they would have expected to obtain had they remained on the job to age 65 . The positive and significant estimates support the bonding theory of severance pay, consistent with Almazan and Suarez (2004), which suggests that firms will guarantee CEOs a certain level of income in order to incent them to make value-increasing risky investments.

The strength of the coefficient estimate for the future compensation variable is modestly 
but not significantly higher if the exiting CEO's departure was forced instead of voluntary. If an interaction term between the compensation variable and a forced turnover indicator is added to the model, it has an insignificantly positive estimate of 0.04 , with the compensation variable's estimate remaining positive and significant at 0.12 .

In Table V's regressions, the variable for expected future compensation per year is set equal to the median annual pay of all sample CEOs, about $\$ 4.4$ million. I recalculate this variable in two ways, using (i) the CEO's total compensation in the last year prior to turnover, and (ii) his average pay for the three years prior to the turnover year (if either of these variables is missing, I continue using the sample median). Estimates for the expected future compensation variable move closer to zero under either of these two specifications. In the left column, the model for the incremental severance package, the coefficient estimates are 0.04 and 0.10 , respectively, with both continuing to have significance at the $1 \%$ level. In the right column, the model for the total severance packages, the estimates fall to 0.02 and 0.05 , respectively, with neither having statistical significance. It is not clear whether median compensation or actual past compensation serves as a better indicator of expected future compensation; one problem with actual past compensation is that it will have been sensitive to performance that may not persist. However, all specifications of the variable are consistent with a conclusion that a positive, significant, but only economically modest connection exists between expected future compensation and the severance pay received by an exiting CEO.

\section{B. Past excess compensation}

As described above, the CEO's excess or above-market compensation for the prior three 
years is based upon the residual from a separate regression of past compensation against firm size, stock performance, and controls for years and industry. For CEOs without a three-year compensation history, the excess compensation variable is set equal to zero.

CEOs' past levels of compensation appear to have little connection to the value of separation pay received. Coefficient estimates for the prior excess compensation variable are close to zero and not statistically significant. The absence of a significant result provides no support for ex post settling up theories of severance pay, which would predict a negative association with past compensation, and also fails to support rent extraction theories, which would predict a positive association. As a sensitivity check, I replace the estimate of prior excess compensation with a variable measuring the value of each CEO's equity holdings in the firm. For most CEOs, the value of equity will be strongly correlated with past compensation, since a majority of CEO pay is received in the form of options or shares that eventually migrate into executives' ownership portfolios. Using the value of equity as a proxy for past compensation does little to change the regression results, as the estimates for the variable remain close to zero and insignificant.

\section{Corporate governance}

I include three governance-related variables in the regressions, since several theories of severance pay predict that the strength of corporate governance will influence the value and form of separation packages. Variables include board size, the percentage of outside directors on the board, and institutional ownership concentration. Institutional concentration is measured as the ratio of the five largest institutional positions divided by total institutional ownership, a statistic 
found by Hartzell and Starks (2003) to have positive associations with various measures of management incentives.

Governance variables appear to have little effect on the value of severance packages, as only one of the six governance-related coefficient estimates in Table $\mathrm{V}$ has statistical significance. That result - suggesting that boards with more outside directors award larger separation packages - appears to contradict both the rent extraction and bonding theories of severance pay, each of which would predict a negative association between pay and an indicator of strong governance such as an outside-controlled board.

However, the governance results must be interpreted with caution, because boards of directors often change their size and composition just prior to planned CEO turnovers (Hermalin and Wesibach, 1988). Specifically, boards tend to increase their size and have a reduced percentage of outside directors, because internal candidates for the CEO post may join the board before the old CEO leaves. Since data indicate that voluntary turnover generally leads to lower severance pay than forced turnover, and since boards are likely to have a lower proportion of outsiders than usual when voluntary turnover occurs, the positive coefficient estimate for the percentage of outside directors might merely capture predictable variation in board composition linked to CEO turnover.

\section{Transparency}

Some companies' separation packages are easy for shareholders to value, since they are delivered in straightforward ways such as lump-sum payments. In other cases, CEOs' severance pay is difficult to value, since it is disclosed only indirectly via changes to pension plans. I 
expect that as severance packages grow larger, firms may disclose them less transparently in order to head off shareholder criticism. I investigate this conjecture in a regression model reported in Table VI. Analysis is limited to the 78 sample observations in which the separation package has positive incremental value.

The dependent variable in the regression is an "opacity index," set equal to the present value of a CEO's pension enhancements divided by the total incremental value of his separation package. This index, which I compound continuously, takes a value between zero and one The key explanatory variable used in the regression is the size of the incremental package compared to its predicted level. This difference is assumed to be the residual from the Tobit regression model in the left column of Table V. I transform this residual into a logged value (or the log of the absolute value, multiplied by -1 , if the residual is negative). Control variables in the regression include return on assets, since profitable firms may be less reluctant to report high compensation; dummy variables for years and two-digit SIC indicators, to reflect time and industry trends in compensation; and a dummy variable that equals one if the firm reports BlackScholes values of stock option awards in its proxy statement. Companies have a choice of valuing options according to Black-Scholes or a simple rule in which the underlying stock price is assumed to appreciate at fixed rates of 5\% and $10 \%$ over the life of the option, and I assume that the election of Black-Scholes disclosure indicates a willingness by a firm to report compensation with greater transparency.

As shown by the regression estimates in Table VI, a significant association exists between the transparency of a CEO's separation package and the extent to which a package is larger than expected. In the right column, I add an interaction term between the residual for the 
size of the separation package and a dummy variable for cases of forced turnover. The interaction term is positive and significant, while its inclusion in the model makes the estimate for the size of the package move toward zero and become insignificant. The results indicate that while firms in general tend to make opaque disclosures of separation packages when they are unexpectedly large, this trend is strongest in cases of forced turnover, when valuable severance might be most objectionable to shareholders.

\section{E. Summary}

Perhaps the clearest implication of the regression analysis is that severance pay has a positive and significant association with expected future compensation for exiting CEOs, whether their departure was forced or voluntary. Neither past over- or under compensation nor measures of corporate governance appear to influence separation packages in systematic ways. Together this evidence is most consistent with the bonding theory of severance pay, and not supportive of the ex post settling up or rent extraction theories. The damage control theory implies no particular predictions about the association of severance pay and other variables.

\section{Stock returns upon disclosure of separation packages}

Companies must disclose separation agreements with current or former CEOs in their annual proxy statements in the section devoted to executive compensation. ${ }^{7}$ I evaluate

\footnotetext{
7 The firm must disclose any agreement that is reached during a year in which the ex-CEO served at any time as CEO, a member of the board, or as one of the company's five most highly compensated officers (including remuneration from the severance package). It is possible that a firm could conclude a separation agreement with an ex-CEO some years after the executive had severed all ties with the company, in which case it might never have to be disclosed. However, it is not clear why negotiations would be ever delayed for so long a period. A dismissed CEO can retain leverage in severance negotiations by refusing to resign from the board of directors until a satisfactory agreement is
} 
shareholder reactions to these agreements by calculating the abnormal stock returns for dates on which the relevant proxy statements are filed with the SEC for the 164 CEOs in the sample. Event dates are the dates on which proxies are posted to the SEC EDGAR public Internet site. Some firms file preliminary proxy statements that are posted on the SEC's website several weeks ahead of final proxy filings, and I use dates for these preliminary proxy postings when available.

The relevant event date for most CEO separation agreements is the first proxy filing date after the CEO leaves office. In a few cases, separation agreements are negotiated in advance of the CEO's departure and disclosed one to two years before he leaves. In other cases, negotiations appear to have become contentious between the firm and CEO, and one must wait one to two years after the CEO's departure for details of his severance package to be published. For CEOs who receive zero separation pay, I use the first proxy statement filing date after their departure as the event date. For CEOs who continue as Chairman of the Board and receive extra compensation, I also use the first proxy filing date after they surrender the CEO job, since the nature of their subsequent compensation as Chairman is usually apparent by that time.

Abnormal stock returns are calculated over an interval beginning four trading days prior to the event day and ending one trading day after. The wider event window seems necessary because companies sometimes mail hard copies of proxy statements to shareholders a few days before the SEC posting date, and sometimes a company's SEC posting takes place after 4:00 p.m. when the stock market has closed until the next day. I calculate cumulative abnormal returns using standard market model methods, with the CRSP value-weighted index as the market portfolio. Results below are generally insensitive to reasonable variations in the

reached. 
estimation procedure, including use of the event date only to calculate abnormal returns as well as the equal-weighted instead of value-weighted market index.

Results shown in Table VII indicate that shareholders have negative and statistically significant reactions to disclosures of CEO severance packages. ${ }^{8}$ For the entire sample, mean cumulative abnormal returns are -0.79 percent, significant at the 5 percent level, when separation agreement terms are disclosed. If the sample is restricted to the $75 \mathrm{CEOs}$ whose agreements had positive incremental value, according to the definition in section III above, the mean abnormal return is more negative, -1.33 percent, again significant at the 5 percent level.

The middle two columns in Table VII illustrate very different market reactions to separation agreements in cases of planned and forced turnover. Planned turnover agreements are accompanied by stock returns more negative than the overall sample average, and the mean abnormal returns are significant below the 1 percent level. In contrast, agreements in cases of forced turnover are accompanied by abnormal stock returns very near zero. The difference between the mean returns for the forced and planned turnover subsamples lies between 1 and 2 percent, depending on the definition used, and is significant at the five percent level.

Shareholder discomfort with separation agreements, but only in cases of voluntary CEO turnover, represents a finding at odds with most theories of severance pay, as shown in Table I. Only the rent extraction theory predicts negative stock returns to the disclosure of severance pacts, while the other theories predict either positive or zero abnormal returns. The return data suggest that shareholders suspect that when CEOs leave on friendly terms, the existence of a severance package may indicate collusion between the CEO and the board to allow the CEO to

\footnotetext{
${ }^{8}$ The table omits four events that took place in 2004, for which CRSP daily stock data is not yet available to enable event study analysis.
} 
extract financial resources. Since the abnormal returns imply a value loss far in excess of the cost of most packages - the sample firms have market capitalizations in range of tens of billions of dollars or more - shareholders may regard the existence of a severance package as a signal of weak governance that could imply other problems for the company.

Regression analysis in Table VIII provides some support for this view. The table shows ordinary least squares estimates for a regression of the cumulative abnormal return against an intercept and a measure of the size of the incremental severance package compared to its expected value, based only upon those observations with positive incremental value. As in the analysis of transparency in Section III.D above, the expected value of each CEO's separation package is assumed to be the predicted value from the Tobit regression estimation in the left column of Table V. I take the difference between the actual incremental value and this expected value, and then take its natural log if the difference is positive. If the difference is negative, I take the natural log of the absolute value and multiply it by -1 . Regression results indicate that abnormal returns are a decreasing function of the size of the incremental severance package compared to its expected level, as the coefficient estimate for this variable is negative and significant below the 1 percent level.

Further regression analysis of abnormal stock returns is inconclusive. I add to the model an interaction term between the unexpected size of the separation package, as defined in the passage above, and an indicator variable for forced turnover. Its estimate is not significant. A separate interaction term based upon the opacity index defined above also yields an insignificant estimate. 


\section{Conclusions}

This paper studies separation payments made to CEOs when they leave their firms, a form of compensation commonly known as "golden handshakes." I find that these packages are extremely widespread and lucrative, with greater frequency and value than the more notorious "golden parachutes" awarded to CEOs when firms are acquired. Close to 80 percent of all CEOs receive separation pay, with a mean value above $\$ 4.5$ million. Frequencies are similar whether a CEO's departure is forced or voluntary, but forced turnovers are generally accompanied by more valuable packages.

I discuss and evaluate four theories for why firms award severance pay, including ex post settling up, bonding, damage control, and rent extraction. Regression analysis of award values supports the bonding theory most closely, with CEOs receiving pay of about 15 cents per dollar of expected future compensation that they might have earned up to age 65 .

Evidence about abnormal stock returns upon the announcement of separation packages has very different implications, however. Shareholders have markedly negative reactions when these agreements are announced, driving stock prices down by more than -1.3 percent if the package has positive value. This share price loss increases as a function of the value of each package compared to its expected level. Negative stock returns are confined to the subsample of CEO turnover events that are voluntary, as abnormal stock returns upon disclosure of severance pay in connection with forced turnover are indistinguishable from zero. These results are not consistent with the bonding theory of severance pay and instead support the rent extraction view, which implies that CEOs might collude with the board to extract lucrative separation agreements as a type of "compensation event." 


\section{References}

Almazan, Andres, and Javier Suarez, 2004, Entrenchment and severance pay in optimal governance structures. Journal of Finance 58, 519-547.

Bebchuk, Lucian, and Jesse Fried, 2004, Pay without performance: The unfulfilled promise of executive compensation. Harvard University Press, Cambridge.

Denis, David, and Diane Denis, 1995, Performance changes following top management dismissals, Journal of Finance 50, 1029-1057.

Fama, Eugene F., 1980, Agency problems and the theory of the firm. Journal of Political Economy 88, 288-307.

Grinstein, Yaniv, and Paul Hribar, 2004, CEO compensation and incentives: Evidence from M\&A bonuses, Journal of Financial Economics 73, 119-143.

Hartzell, Jay C., Eli Ofek, and David Yermack, 2004, What's in it for me? CEOs whose firms are acquired, Review of Financial Studies 17, 37-61.

Hartzell, Jay C., and Laura T. Starks, 2003, Institutional investors and executive compensation, Journal of Finance 53, 2351-2374.

Hermalin, Benjamin E., and Michael S. Weisbach, 1988, The determinants of board composition, RAND Journal of Economics 19, 589-606.

Huson, Mark R., Robert Parrino, and Laura Starks, 2001, Internal monitoring mechanisms and CEO turnover: A long-term perspective, Journal of Finance 56, 2265-2297.

Yermack, David, 1996, Higher market valuation of companies with a small board of directors, Journal of Financial Economics 40, 185-212. 


\section{Table I}

\section{Theories of severance pay and empirical predictions}

Four leading theories of why CEOs receive valuable separation agreements. Each theory is presented along with empirical predictions about which CEOs should receive severance packages, how the packages should be associated with other variables, and whether company stock prices should react to the publication of a CEO's severance award. Section I of the text describes each theory more fully.

\begin{tabular}{llll} 
Theory & $\begin{array}{l}\text { When do CEOs } \\
\text { receive severance? }\end{array}$ & $\begin{array}{l}\text { Associations with } \\
\text { Ex post } \\
\text { settling up variables }\end{array}$ & $\begin{array}{l}\text { Stock price } \\
\text { reaction }\end{array}$ \\
\hline Bonding & $\begin{array}{l}\text { Both voluntary and } \\
\text { forced retirements }\end{array}$ & $\begin{array}{l}\text { Expected future } \\
\text { compensation }(+)\end{array}$ & $\begin{array}{l}\text { Pone expected } \\
\text { forced retirements }\end{array}$ \\
& $\begin{array}{l}\text { Past } \\
\text { over-compensation }(-)\end{array}$ & \\
\hline $\begin{array}{l}\text { Damage } \\
\text { control }\end{array}$ & $\begin{array}{l}\text { More often for forced } \\
\text { retirements }\end{array}$ & None expected & Positive \\
\hline $\begin{array}{l}\text { Rent } \\
\text { extraction }\end{array}$ & Voluntary retirements & Weak governance $(+)$ & Negative \\
& & $\begin{array}{l}\text { Past } \\
\text { over-compensation }(+)\end{array}$ & $\begin{array}{l}\text { Increasingly negative if } \\
\text { pay is not transparent }\end{array}$
\end{tabular}




\section{Table II \\ Sample selection}

Sample selection procedure for observations used in a study of CEO separation agreements. The candidate sample includes seven annual observations for each of 237 Fortune 500 firms that were public between 1996 and 2002 and are covered by ExecuComp. CEO turnover events are excluded from the analysis for certain extraordinary reasons listed in the table. Excluded events either did not require the board to decide about the terms of the CEO's separation, or involved significant external considerations in conjunction with the CEO turnover. Non-retirements refer to cases in which the exiting CEO remained an officer of the firm, usually as Chairman, for an indefinite period at a compensation level equal to or greater than the successor CEO. Planned and involuntary turnover events are identified mainly from news reports and language in company proxy statements.

Total sample: 237 firms x 7 years

CEO turnover events

Events excluded from analysis

Non-retirements

Succession agreements in mergers

Acting CEOs

Resigned to take better position

Death or poor health

Resigned in connection with spinoff

Cause (fraud, drugs, sexual harassment)

Data omitted from SEC filings

Final sample for analysis

Involuntary turnover

Planned turnover
1,659 candidate observations

\section{$211 \quad 12.7 \%$ of sample}

16

164 observations

$43 \quad 26.2 \%$ of analyzed sample

$121 \quad 73.8 \%$ 


\section{Table III \\ Descriptive statistics}

Descriptive statistics for a sample of 164 CEOs who left their positions in Fortune 500 firms between 1996 and 2002. The value of options is computed according to the Black-Scholes method. The actuarial value of pensions is based upon payout information in firms' proxy statements, augmented by insurance industry mortality tables and firms' costs of debt as inferred from bond ratings. Prior year compensation includes salary, bonus, option awards, and restricted stock awards. Three-year excess compensation is based upon the residual from a regression of the log of compensation against the log of firm size, net of market three-year stock return, and industry and year dummy variables; this variable is missing for CEOs with less than three years tenure. Board of directors data is obtained from Compact Disclosure, institutional ownership data is obtained from CDA/Spectrum, and financial data is obtained from ExecuComp.

Observations

Age of exiting CEO

Years tenure in office

Value of shares and options, (mean)

end of prior year (millions) (median)

Actuarial value of pension, (mean)

end of prior year (millions) (median)

Compensation in prior year

(millions)

Three-year excess compensation (millions)

Next position with firm

(mean)

(median)

(mean)

(median)

$\begin{array}{lc}\text { Chairman } & 95 \\ \text { Vice Chm. } & 1 \\ \text { Director } & 18 \\ \text { None } & 50\end{array}$

Board size

Outside directors

Institutional ownership

Total assets (billions) (mean)

(mean)

(mean)

(mean) (median)

\section{Full sample}

164

61

9

$\$ 92.2$

$\$ 34.7$

$\$ 6.4$

$\$ 4.5$

$\$ 8.1$

$\$ 4.4$

$\$ 6.2$

$\$ 0.0001$
Planned

121

63

10

$\$ 95.4$

$\$ 43.9$

$\$ 7.6$

$\$ 5.4$

$\$ 7.7$

$\$ 4.1$

$\$ 5.5$

$\$ 0.2$

84

1

15

21

12.7

$76.3 \%$

$62.0 \%$

$\$ 38.9$

$\$ 35.9$

$\$ 11.6$

$\$ 11.3$
Forced 43

\section{6}

6

$\$ 83.1$

$\$ 22.5$

$\$ 3.2$ b

$\$ 2.4$

$\$ 9.5$

$\$ 6.2$

$\$ 10.5$

(\$1.0)

11

0

3

29

11.7

$76.9 \%$

$60.6 \%$

$\$ 27.5$

Differences in right two columns are significant at 1\% (a), 5\% (b), and 10\% (c) levels, according to T-tests (means) and Wilcoxon rank-sum tests (identical distributions). 


\section{Table IV}

\section{CEO compensation upon separation}

Descriptive statistics for compensation paid to CEOs of 164 Fortune 500 companies after leaving their positions. All values are in millions, and when payments are spread over time, data reflect present values discounted at the company's cost of debt. Compensation as Chairman refers to pay received by CEOs who remain Chairman after leaving the CEO post, not including routine directors' fees. Equity forfeiture value includes the change in Black-Scholes value of options that are truncated or surrendered. Information is obtained from company proxy statements.

\begin{tabular}{|c|c|c|c|c|c|c|c|}
\hline$\underline{\text { All observations }}$ & Freq. & $\underline{\text { Mean }}$ & & Median & $\underline{75 \%}$ ile & $\underline{\text { Max. }}$ & \\
\hline Lump-sum payments & $24 \%$ & $\$ 1.05$ & & 0 & 0 & $\$ 21.86$ & \\
\hline Consulting or non-compete & $25 \%$ & $\$ 0.53$ & & 0 & $\$ 0.03$ & $\$ 9.50$ & \\
\hline Augmentation of pension & $20 \%$ & $\$ 0.96$ & & 0 & $\$ 5.89$ & $\$ 15.53$ & \\
\hline Forfeiture of stock or options & $5 \%$ & $(\$ 0.20)$ & & $\underline{0}$ & 0 & $(\$ 10.86)$ & \\
\hline Sub-total: incremental pay & $48 \%$ & $\$ 2.38$ & & $\mathbf{0}$ & $\$ 2.53$ & $\$ 22.83$ & \\
\hline Employment contract payoff & $16 \%$ & $\$ 0.96$ & & 0 & 0 & $\$ 36.09$ & \\
\hline Compensation as Chairman & $46 \%$ & $\$ 1.21$ & & $\underline{0}$ & $\$ 0.97$ & $\$ 42.46$ & \\
\hline Total pay & $79 \%$ & $\$ 4.51$ & & $\$ \$ 1.82$ & $\$ 5.89$ & $\$ 43.60$ & \\
\hline \multicolumn{8}{|l|}{ Planned turnover cases } \\
\hline Lump-sum payments & $19 \%$ & $\$ 0.96$ & & 0 & 0 & $\$ 21.86$ & \\
\hline Consulting or non-compete & $21 \%$ & $\$ 0.31$ & & 0 & 0 & $\$ 6.10$ & \\
\hline Augmentation of pension & $13 \%$ & $\$ 0.57$ & & 0 & 0 & $\$ 11.10$ & \\
\hline Forfeiture of stock or options & $1 \%$ & $(\$ 0.03)$ & & $\underline{0}$ & 0 & $(\$ 3.18)$ & \\
\hline Sub-total: incremental pay & $41 \%$ & $\$ 1.82$ & & $\overline{\mathbf{0}}$ & $\$ 1.03$ & $\$ 21.86$ & \\
\hline Employment contract payoff & $7 \%$ & $\$ 0.15$ & & 0 & 0 & $\$ 4.76$ & \\
\hline Compensation as Chairman & $55 \%$ & $\$ 1.62$ & & $\$ 0.23$ & $\$ 1.52$ & $\$ 42.46$ & \\
\hline Total pay & $78 \%$ & $\$ 3.60$ & & $\$ 1.38$ & $\$ 4.68$ & $\$ 43.47$ & \\
\hline \multicolumn{8}{|l|}{ Involuntary turnover cases } \\
\hline$\overline{\text { Lump-sum payments }}$ & $37 \%$ & $\$ 1.28$ & & 0 & $\$ 0.83$ & $\$ 10.44$ & a \\
\hline Consulting or non-compete & $37 \%$ & $\$ 1.16$ & a & 0 & $\$ 1.97$ & $\$ 9.50$ & a \\
\hline Augmentation of pension & $40 \%$ & $\$ 2.05$ & a & 0 & $\$ 2.27$ & $\$ 15.53$ & a \\
\hline Forfeiture of stock or options & $19 \%$ & $(\$ 0.69)$ & a & 0 & 0 & $(\$ 10.86)$ & a \\
\hline Sub-total: incremental pay & $65 \%$ & $\$ 3.94$ & a & $\$ \$ 0.78$ & $\$ \$ \$ 7.32$ & $\$ 22.83$ & $\mathrm{~b}$ \\
\hline Employment contract payoff & $40 \%$ & $\$ 3.24$ & a & 0 & $\$ 1.96$ & $\$ 36.09$ & a \\
\hline Compensation as Chairman & $19 \%$ & $\$ 0.07$ & $\mathrm{~b}$ & 0 & 0 & $\$ 0.64$ & \\
\hline Total pay & $84 \%$ & $\$ 7.11$ & a & $\$ 4.15$ & $\$ \$ 10.19$ & $\$ 43.60$ & a \\
\hline
\end{tabular}




\section{Table V \\ Tobit regression estimates: value of separation agreement}

Tobit regression estimates of the value of separation agreements for 164 Fortune 500 CEOs who left their positions between 1996 and 2002. The total package includes lump-sum payments, pension enhancements, consulting and non-compete agreements, forfeitures of equity awards, compensation for service as chairman of the board, and payouts made under existing employment contracts. The incremental package includes the first four of these six types of compensation. Excess compensation for the prior three years is based upon the residual from a standard compensation regression model and equals zero for CEOs with less than three years tenure. Expected future compensation is the present value of median annual compensation for the sample of CEOs, projected until age 65 for each individual and discounted at each firm's cost of debt. Expected future compensation equals zero for CEOs age 65 and older. Institutional investor concentration is the ownership of the five largest institutional investors divided by total institutional ownership. Standard errors appear in parentheses below each coefficient estimate.

\begin{tabular}{|c|c|c|}
\hline Dependent variable (\$ millions) & $\begin{array}{c}\text { Incremental } \\
\text { Package }\end{array}$ & $\begin{array}{c}\text { Total } \\
\text { Package }\end{array}$ \\
\hline & Estimate & Estimate \\
\hline Intercept & $\begin{array}{l}-26.45 \\
(13.20)\end{array}$ & $\begin{array}{l}-40.09 \\
(12.73)\end{array}$ \\
\hline Expected future compensation (present value) & $\begin{array}{c}0.14 \\
(0.06)\end{array}$ & $\begin{array}{c}0.15 \\
(0.05)\end{array}$ \\
\hline Excess compensation, prior three years & $\begin{array}{c}-0.03 \\
(0.03)\end{array}$ & $\begin{array}{c}0.02 \\
(0.03)\end{array}$ \\
\hline Firm size (log of total assets) & $\begin{array}{l}2.46 \\
(0.77)\end{array}$ & $\begin{array}{c}0.57 \\
(0.73)\end{array}$ \\
\hline Board size (log) & $\begin{array}{l}-3.23 \\
(3.30)\end{array}$ & $\begin{array}{l}2.55 \\
(3.12)\end{array}$ \\
\hline Board composition ( $\%$ outside directors) & $\begin{array}{c}3.07 \\
(10.30)\end{array}$ & $\begin{array}{c}30.72 \\
(10.09)\end{array}$ \\
\hline Institutional ownership concentration & $\begin{array}{c}1.46 \\
(8.95)\end{array}$ & $\begin{array}{l}-5.59 \\
(8.32)\end{array}$ \\
\hline Year dummy variables & Yes & Yes \\
\hline Industry dummy variables (two-digit) & Yes & Yes \\
\hline Total observations & 164 & 164 \\
\hline Positive observations & 78 & 130 \\
\hline
\end{tabular}

\section{Table VI}




\section{Opacity of separation agreement as a function of its value}

OLS regression estimates of the ratio of opaque CEO severance pay over the CEO's entire severance package. The sample includes all 78 observations of CEO separation agreements with positive incremental value, from a sample of 164 CEO turnover events in Fortune 500 firms between 1996 and 2002. Components of the incremental value of severance packages are identified in Table IV. The dependent variable in the regressions is a ratio between 0 and 1 , equal to the value of pension enhancements included in a CEO's severance package, divided by the total incremental value of the package, with the quotient compounded continuously. A lower value of the dependent variable implies greater transparency. The main explanatory variable is the log of the absolute value of the residual from the regression model in the left column of Table V, which estimates the expected value of each CEO's incremental separation package, multiplied by -1 if the residual is negative. Return on assets equals operating income before depreciation and amortization, divided by total assets at the start of the fiscal year and compounded continuously. The Black-Scholes report indicator equals 1 if a firm reports BlackScholes option values in its disclosure of executive stock option awards, and equals 0 if the firm instead reports hypothetical future option values. Standard errors appear below each estimate in parentheses.

Dependent variable: Present value of pension enhancements / total incremental package

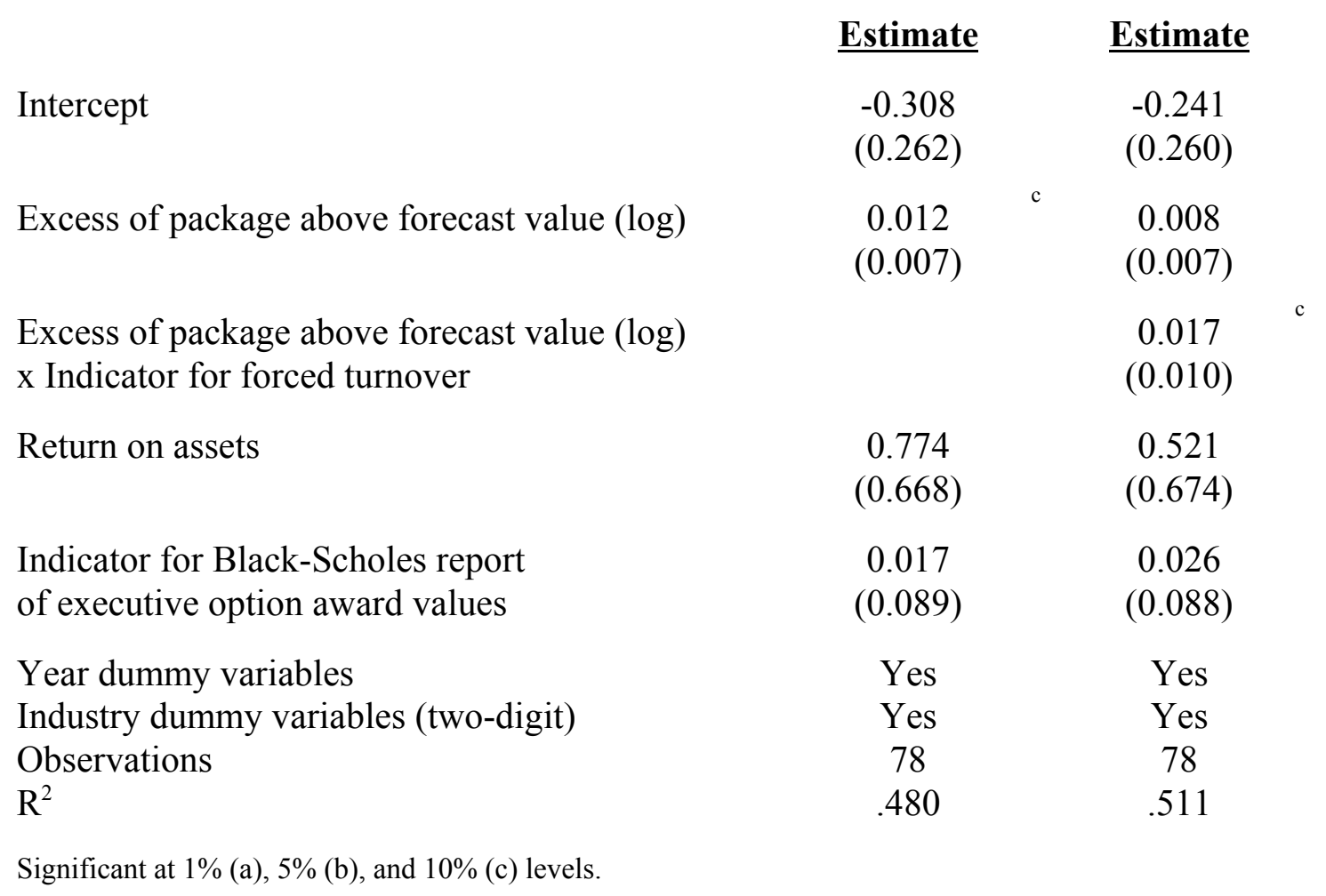




\section{Table VII}

\section{Abnormal stock returns at announcement of separation packages}

Mean cumulative abnormal stock returns around the disclosure of separation agreements for a sample of 164 exiting CEOs of Fortune 500 companies between 1996 and 2002. Abnormal returns are calculated for an event window beginning four days prior to the disclosure date and ending one day after, using standard market model methodology. Disclosure dates are the dates on which the relevant proxy statement or preliminary proxy is posted on the SEC's EDGAR website. The top rows of the table includes data for the entire sample (except for four disclosure events that took place in 2004 for which CRSP data is not yet available). The bottom rows omit observations for exiting CEOs who received zero incremental compensation at their time of separation, as well as a handful of CEOs whose separation agreements had negative net value due to the forfeiture or truncation of equity awards.

$\underline{\text { All observations }}$

Observations

Cumulative abnormal return

T-statistic

Separation packages

with positive incremental value

Observations

Cumulative abnormal return

T-statistic

\begin{tabular}{|c|c|c|c|}
\hline Full & Planned & Forced & $\frac{\text { (Forced - }}{\text { Planned) }}$ \\
\hline$\underline{\text { Sample }}$ & turnover & turnover & Difference \\
\hline 160 & 120 & 40 & \\
\hline$-0.79 \%$ & $-1.07 \%$ & $0.04 \%$ & $1.11 \%$ \\
\hline$-2.29^{b}$ & $-2.53^{b}$ & -0.20 & $2.36^{\mathrm{b}}$ \\
\hline 75 & 49 & 26 & \\
\hline$-1.33 \%$ & $-1.92 \%$ & $-0.20 \%$ & $1.73 \%$ \\
\hline$-2.45^{b}$ & $-2.59^{a}$ & -0.60 & $2.14^{\mathrm{b}}$ \\
\hline
\end{tabular}

Significant at 1\% (a), 5\% (b), and 10\% (c) levels. 


\section{Table VIII}

\section{Abnormal stock returns as a function of separation agreement value}

OLS regression estimates of the magnitude of cumulative abnormal stock returns upon the announcement of CEOs' separation packages. The sample includes all 78 observations of CEO separation agreements with positive incremental value, from a sample of 164 CEO turnover events in Fortune 500 firms between 1996 and 2002. Announcement dates are obtained from company proxy statement or preliminary proxy filing dates, and abnormal returns are measured over an interval from four days prior until one day after the announcement date. The main explanatory variable is the log of the absolute value of the residual from the regression model in the left column of Table $\mathrm{V}$, which estimates the expected value of each CEO's incremental separation package, multiplied by -1 if the residual is negative. Standard errors appear below each estimate in parentheses. (Three observations are missing from the regression because the event period did not occur until 2004.)

Dependent variable: Cumulative abnormal stock return upon announcement of package

\section{Estimate}

Intercept

0.0066

(0.0098)

Excess of package above forecast value (log)

$-0.0036$

$(0.0012)$

Observations

$\mathrm{R}^{2}$

Significant at $1 \%(\mathrm{a}), 5 \%(\mathrm{~b})$, and $10 \%$ (c) levels. 